\title{
ANALISIS PROSES PENATAUSAHAAN BELANJA PADA PEMERINTAH DESA ONGKAW TIGA KECAMATAN SINONSAYANG MINAHASA SELATAN BERDASARKAN PERMENDAGRI NOMOR 113 TAHUN 2014
}

\author{
Ridhwan Muhammad Isma'il Pakaja ${ }^{1}$, Jantje J. Tinangon ${ }^{2}$, Dhullo Afandi ${ }^{2}$ \\ ${ }^{1,2}$ Jurusan Akuntansi, Fakultas Ekonomi dan Bisnis, Universitas Sam Ratulangi, J1. Kampus Bahu, Manado, \\ 95115, Indonesia \\ ${ }^{1}$ E-mail: kabitaponaryo@gmail.com
}

\begin{abstract}
Good village financial management is an important aspect in the success of village development and community welfare. Moreover, each year the funds allocated to each village have increased. Good village financial management is management that is in accordance with guidelines set by the government, which is contained in Permendagri Number 113 of 2014 concerning Village Financial Management. The purpose of this study is to analyze the adequacy of village financial management, especially in the process of expenditure administration organized by the Ongkaw Tiga Village Government. In this study, the type of data used is qualitative data, while for data sources using primary data, and the analytical method used is descriptive analysis method. Based on the results of the study, it was concluded that in the preparation of the RAB, filing employee expenditure, filing SPP on goods and services spending, filing SPP capital expenditure almost everything done by the Ongkaw Tiga village government can be said to be not complied with. After the evaluation, the factors that influence the non-compliance of the village government in carrying out the procedures for submitting village expenditures are the lack of knowledge and understanding of the village apparatus from the Village Head to the Implementing Officer on the rules imposed so that there are many errors in the preparation or preparation of these documents.

Keywords: village financial management; expenditure administration; village spending
\end{abstract}

\section{PENDAHULUAN}

Desa adalah kesatuan masyarakat hukum yang memiliki batas wilayah yang berwenang untuk mengatur dan mengurus urusan pemerintahan, kepentingan masyarakat setempat berdasarkan prakarsa masyarakat, hak asal usul, dan/atau hak tradisional yang diakui dan dihormati dalam sistem pemerintahan Negara Kesatuan Republik Indonesia (Noverman, 2018). Dengan disahkannya Undang-undang Nomor 6 tahun 2014 tentang desa, maka desa diberikan kewenangan atau kesempatan yang besar untuk mengurus tata pemerintahannya sendiri serta pelaksanaan pembangunan untuk meningkatkan kesejahteraan dan kualitas hidup masyarakat desa. Selain itu, pemerintah desa diharapkan untuk lebih mandiri dalam mengelola pemerintahan dan berbagai sumber daya alam yang dimiliki, termasuk di dalamnya pengelolaan keuangan desa dan kekayaan milik desa (Mamesah, 2015). Di satu sisi pemerintah desa akan memperoleh dana yang sangat besar dalam menjalankan roda pemerintahan desa, tetapi di sisi lain dituntut pengelolaan keuangan desa yang lebih baik yaitu transparan, akuntabel, partisipatif serta dilakukan dengan tertib dan disiplin anggaran (Usman dan Haryanto, 2015).

Pengelolaan keuangan desa yang baik merupakan aspek penting dalam menyukseskan pembangunan desa dan kesejahteraan masyarakat. Terlebih lagi setiap tahun dana yang dialokasikan pada setiap desa mengalami kenaikan (Nafidah dan Anisa, 2017). Pengelolaan keuangan desa yang baik adalah pengelolaan yang sesuai dengan pedoman yang telah diatur oleh pemerintah. Berdasarkan Permendagri Nomor 113 Tahun 2014 tentang Pengelolaan 
Keuangan Desa, pengelolaan keuangan desa adalah keseluruhan kegiatan yang meliputi perencanaan, pelaksanaan, penatausahaan, pelaporan, dan pertanggungjawaban keuangan desa. Pada pengelolaan keuangan desa, Kepala Desa dibantu oleh Tim Pelaksana yang terdiri dari perangkat desa sesuai Permendagri Nomor 113 Tahun 2014 Bab III Pasal 4, dimana bahwa yang dimaksud sebagai Tim Pengelola Keuangan Desa yaitu Kepala Desa, Sekretaris Desa, Bendahara Desa, dan Kepala Seksi (Setiawan et al., 2017). Pada pengelolaan keuangan desa, dalam hal ini pelaksanaan APBDes harus memiliki pengendalian internal serta sistem akuntansi yang baik dan memadai agar supaya kualitas laporan keuangan yang dihasilkan bisa dipertanggungjawabkan dengan jelas (Gimon et al., 2018).

Pada beberapa tahun yang lalu sebelum pergantian Hukum Tua periode saat ini, di Desa Ongkaw Tiga dalam kegiatan-kegiatan pembangunan desa, pemerintah desa yang ditugaskan sebagai pelaksana kegiatan seringkali kurang tepat dalam pembuatan laporan pertanggungjawaban. Misalnya, kurang tepat dalam menggunakan format-format dalam penyusunan laporan, serta tidak menyertakan dokumen-dokumen bukti transaksi atas belanja desa secara lengkap. Hal ini disebabkan oleh kurangnya pengetahuan dari pelaksana kegiatan atas aturan-aturan yang diberlakukan. Tujuan penelitian ini adalah untuk menganalisis proses penatausahaan yang diselenggarakan oleh pemerintah Desa Ongkaw Tiga dalam pelaksanaan belanja desa.

\section{TINJAUAN PUSTAKA}

Akuntansi sektor publik. Menurut Halim (2012:3), akuntansi sektor publik adalah suatu proses pengidentifikasian, pengukuran, pencatatan dan pelaporan transaksi ekonomi (keuangan) dari suatu organisasi atau entitas publik seperti pemerintah, Lembaga Survey Masyarakat (LSM), dan lain-lain yang dijadikan sebagai informasi dalam rangka mengambil keputusan ekonomi oleh pihak-pihak yang memerlukan. Akuntansi sektor publik adalah aktivitas jasa yang terdiri dari mencatat, mengklasifikasikan dan melaporkan kejadian atau transaksi ekonomi yang akhirnya akan menghasilkan suatu informasi keuangan yang akan dibutuhkan oleh pihak-pihak tertentu untuk pengambilan keputusan yang diterapkan pada pengelolaan dana publik di lembaga-lembaga tinggi negara dan departemen-departemen dibawahnya (Wiratna, 2015:1).

Akuntansi pemerintahan. Menurut Sadeli (2015:5), akuntansi pemerintahan dapat didefinisikan sebagai suatu aktivitas pemberian jasa untuk menyediakan informasi keuangan pemerintah berdasarkan proses pencatatan, pengklasifikasian, pengikhtisaran suatu transaksi keuangan pemerintahan serta informasi keuangan tersebut.

Sistem akuntansi. Mulyadi (2016:3) menjelaskan bahwa sistem akuntansi adalah organisasi formulir, catatan, dan laporan yang dikoordinasikan sedemikian rupa untuk menyediakan informasi keuangan yang dibutuhkan oleh manajemen guna memudahkan pengelolaan perusahaan. Sistem akuntansi yang dirancang dan dijalankan secara baik akan menjamin dilakukannya prinsip stewardship dan accountability dengan baik pula. Pemerintah atau unit kerja pemerintah perlu memiliki sistem akuntansi yang tidak hanya berfungsi sebagai alat pengendalian transaksi keuangan, akan tetapi sistem akuntansi tersebut hendaknya mendukung pencapaian tujuan organisasi.

Sistem akuntansi desa. Menurut Permendagri Nomor 113 tahun 2014, pengelolaan keuangan desa adalah keseluruhan kegiatan yang meliputi perencanaan, pelaksanaan, penatausahaan, pelaporan, dan pertanggungjawaban keuangan desa. Menurut Permendagri Nomor 113 Tahun 2014, keuangan desa adalah semua hak dan kewajiban desa yang dapat dinilai dengan uang serta segala sesuatu berupa uang dan barang yang berhubungan dengan pelaksanaan hak dan kewajiban desa.

Pengelolaan keuangan desa. Menurut Lapananda (2016:3), pengelolaan keuangan desa adalah keseluruhan proses kegiatan mulai dari perencanaan, pelaksanaan, 
penatausahaan, pelaporan, pertanggungjawaban, serta pembinaan dan pengawasan keuangan desa. Keuangan desa dikelola berdasarkan asas-asas transparan, akuntabel, partisipatif serta dilakukan dengan tertib dan disiplin anggaran. Pengelolaan keuangan desa dikelola dalam masa 1 (satu) tahun anggaran yakni mulai tanggal 1 Januari sampai dengan tanggal 31 Desember. Pelaksanaan belanja desa dan seluruh kegiatan aktivitas prosedur penatausahaannya telah diatur dalam Permendagri Nomor 113 Tahun 2014. Adapun aturannya sebagai berikut :

1. Semua penerimaan dan pengeluaran desa dalam rangka pelaksanaan kewenangan desa dilaksanakan melalui rekening kas desa.

2. Khusus bagi desa yang belum memiliki pelayanan perbankan di wilayahnya maka pengaturannya ditetapkan oleh Pemerintah Kabupaten/Kota.

3. Semua penerimaan dan pengeluaran desa harus didukung oleh bukti yang lengkap dan sah.

4. Pemerintah desa dilarang melakukan pungutan sebagai penerimaan desa

5. Bendahara dapat menyimpan uang dalam Kas Desa pada jumlah tertentu dalam rangka memenuhi kebutuhan operasional pemerintah desa.

6. Pengeluaran desa yang mengakibatkan beban APBDes tidak dapat dilakukan sebelum rancangan peraturan desa tentang APBDes ditetapkan menjadi peraturan desa.

7. Pengeluaran desa tidak termasuk untuk belanja pegawai yang bersifat mengikat dan operasional perkantoran yang ditetapkan dalam peraturan kepala desa.

8. Penggunaan biaya tak terduga terlebih dulu harus dibuat Rincian Anggaran Biaya yang telah disahkan oleh Kepala Desa.

9. Pelaksana Kegiatan mengajukan pendanaan untuk melaksanakan kegiatan harus disertai dengan dokumen antara lain Rencana Anggaran Biaya.

10. Rencana Anggaran Biaya di verifikasi oleh Sekretaris Desa dan di sahkan oleh Kepala Desa.

11. Pelaksana Kegiatan bertanggungjawab terhadap tindakan pengeluaran yang menyebabkan atas beban anggaran belanja kegiatan dengan mempergunakan buku pembantu kas kegiatan sebagai pertanggungjawaban pelaksanaan kegiatan di desa.

12. Berdasarkan rencana anggaran biaya pelaksana kegiatan mengajukan Surat Permintaan Pembayaran (SPP) kepada Kepala Desa.

13. Surat Permintaan Pembayaran (SPP) tidak boleh dilakukan sebelum barang dan atau jasa diterima.

14. Pengajuan SPP terdiri atas Surat Permintaan Pembayaran (SPP), pernyataan tanggungjawab belanja, dan lampiran bukti transaksi.

15. Dalam pengajuan pelaksanaan pembayaran sekretaris desa berkewajiban untuk meneliti kelengkapan permintaan pembayaran di ajukan oleh pelaksana kegiatan, menguji kebenaran perhitungan tagihan atas beban APBDes yang tercantum dalam permintaan pembayaran, menguji ketersedian dana untuk kegiatan dimaksud dan menolak pengajuan permintaan pembayaran oleh pelaksana kegiatan apabila tidak memenuhi persyaratan yang ditetapkan.

16. Berdasarkan SPP yang telah di verifikasi Sekretaris Desa, Kepala Desa menyetujui permintaan pembayaran dan bendahara melakukan pembayaran.

17. Pembayaran yang telah dilakukan, selanjutnya bendahara melakukan pencatatan pengeluaran.

18. Bendahara desa sebagai wajib pungut Pajak Penghasilan $(\mathrm{PPh})$ dan pajak lainnya, wajib menyetorkan seluruh penerimaan potongan dan pajak yang dipungutnya ke rekening kas negara sesuai dengan ketentuan peraturan perundang-undangan.

Sistem Pengendalian Internal. Internal Control menurut Committee of Sponsoring Organizations of the Treadway Commission/COSO (2013) adalah suatu proses yang 
dijalankan oleh dewan direksi, manajemen, dan staf, untuk membuat reasonable assurance mengenai: (a) efektifitas dan efisiensi operasional; (b) reliabilitas pelaporan keuangan; dan (c) kepatuhan atas hukum dan peraturan yang berlaku. Menurut COSO framework, pengendalian internal terdiri dari 5 (lima) komponen yang saling terkait, yaitu: (1) lingkungan pengendalian (control environment); (2) penaksiran risiko (risk assessment); (3) kegiatan pengendalian (control activities); (4) informasi dan komunikasi (information and communication); dan (5) kegiatan pemantauan (monitoring activites).

Penelitian terdahulu. Mamesah (2015) menemukan bahwa Badan Permusyawaratan Desa masih memerlukan penguatan kapasitas kelembagaan. Usman dan Haryanto (2015) menunjukkan bahwa pemerintah Desa Pelawad telah memahami mekanisme pertanggungjawaban keuangan desa. Setiawan et al. (2017) menunjukkan bahwa penyaluran Alokasi Dana Desa (ADD) dari Pemerintah Daerah ke Pemerintah Desa Bengkel sudah mengacu pada Peraturan Bupati Nomor 84 Tahun 2015 tentang tata cara pengalokasian Dana Desa, Alokasi Dana Desa, Bagi Hasil Pajak, dan Bagi Hasil Retribusi dan pencairan dana dilakukan melalui 4 (empat) tahap yang dilengkapi dengan surat rekomendasi dari kecamatan. Tangkaroro et al. (2017) menemukan bahwa Desa Tincep Kecamatan Sonder Kabupaten Minahasa telah menerapkan sistem dan pencatatan akuntansi sesuai Permendagri No. 113/2014 dan Peraturan Menteri Keuangan Nomor 49/PMK.07/2016.

\section{METODE PENELITIAN}

Jenis data yang digunakan dalam penelitian ini adalah: (1) data kualitatif, berupa hasil wawancara, sejarah desa, struktur desa, maupun hal-hal yang berkaitan dengan Desa Ongkaw Tiga Kecamatan Sinonsayang Minahasa Selatan; dan (2) data kuantitatif, yaitu hasil dokumentasi berupa dokumen-dokumen mengenai belanja di Desa Ongkaw Tiga. Sumber data yang digunakan adalah data primer. Data primer diperoleh dari hasil wawancara secara langsung dengan Kepala Desa, Sekretaris Desa dan Bendahara Desa. Data primer penelitian ini adalah sejarah desa, struktur desa, dan dokumen-dokumen mengenai belanja di Desa Ongkaw Tiga. Metode analisis data yang digunakan adalah metode analisis deskriptif. Data dikumpulkan, disusun, diinterpretasikan dan dianalisis sehingga memberikan keterangan yang lengkap bagi masalah yang dihadapi.

\section{HASIL PENELITIAN DAN PEMBAHASAN}

\subsection{Hasil penelitian}

Penatausahaan belanja. Penelitian ini meneliti tentang prosedur Rencana Anggaran Biaya (RAB) hingga aktivitas yang terkait dengan Penatausahaan Belanja. Berdasarkan laporan realisasi pelaksanaan APBDes Desa Ongkaw Tiga bahwa klasifikasi jenis-jenis belanja yang terdapat pada APBDes Ongkaw Tiga ada 3 (tiga) jenis belanja, yaitu:

1. Belanja pegawai. Merupakan belanja yang digunakan untuk pengeluaran dan penghasilan tetap dan tunjangan bagi Kepala Desa dan perangkat desa serta tunjangan BPD. Belanja ini dianggarkan ke dalam kelompok belanja penyelengaraan pemerintah desa, dengan kegiatan berupa pembayaran penghasilan tetap dan tunjangan.

2. Belanja barang dan jasa. Merupakan belanja yang digunakan untuk pengeluaran pembelian atau pengadaan barang yang nilai manfaatnya kurang dari 12 (dua belas) bulan. Belanja barang dan jasa yang ada di Desa Ongkaw Tiga yaitu alat tulis kantor, benda pos, makan minum, perjalanan dinas, cetak dan penggandaan.

3. Belanja modal. Merupakan belanja yang digunakan untuk pengeluaran dalam rangka pengadaan barang atau bangunan yang nilai manfaatnya lebih dari 12 (dua belas) bulan serta digunakan untuk kegiatan penyelenggaraan kewenangan desa. Misalnya, belanja bahan-bahan bangunan, peralatan mebel seperti lemari, pintu dan lain-lain. 
Prosedur pengajuan Rencana Anggaran Biaya (RAB). Penggunaan dokumen Rencana Anggaran Biaya (RAB) di Desa Ongkaw Tiga hanya digunakan untuk belanja yang bersifat pengadaan barang atau bangunan yang nilai manfaatnya lebih dari 12 (dua belas) bulan serta digunakan untuk kegiatan penyelengaraan kewenangan desa. Misalnya, belanja bahan-bahan bangunan. Adapun prosedur yang terjadi sampai diterbitkannya dokumen RAB di Desa Ongkaw Tiga, yaitu:

1. Setelah ditetapkan RPJM, Badan Permusyawaratan Desa (BPD) mengundang Pemerintah Desa, Lembaga Pemberdayaan Masyarakat (LPM), dan Tokoh Masyarakat untuk membuat musyawarah tentang penyusunan Rencana Kerja Pemerintah (RKP).

2. Pemerintah desa membentuk tim panitia RKP yang diketahui oleh Sekretaris Desa dan beranggotakan 7 (tujuh) orang yang terdiri dari perangkat desa dan LPM.

3. Menyusun rencana kerja pemerintah desa termasuk di dalamnya disusun APBDes selama 1 (satu) tahun ke depan sesuai dengan hasil kesepakatan dari musyawarah RKP.

4. Setelah ditetapkan APBDes, Kepala Desa menunjuk/menentukan Tim Pelaksana Kegiatan untuk melaksanakan kegiatan yang sudah dirumuskan oleh panitia penyusun RKP antara lain bidang pembangunan, pembinaan kemasyarakatan dan pemberdayaan.

5. Untuk bidang pembangunan, Tim Pelaksana Kegiatan melakukan survei/pemetaan lokasi untuk dilaksanakan pembangunan fisik.

6. Berdasarkan hasil perhitungan pada survei tersebut, tim pelaksana kegiatan menyusun rincian $\mathrm{RAB}$. Dalam penyusunan RAB dicantumkan keterangan tentang kegiatan yang akan dilaksanakan antara lain, jenis kegiatan, kegiatan, lokasi, volume, dan rincian pendanaan.

7. Setelah RAB tersusun, pelaksana kegiatan menandatangani RAB tersebut.

berikut:

Prosedur pengajuan belanja pegawai. Prosedur ini terdiri dari kegiatan-kegiatan

1. Sumber dana yang dipakai untuk belanja pegawai di Desa Ongkaw Tiga yaitu berasal dari alokasi dana desa.

2. Belanja pegawai di Desa Ongkaw Tiga dilakukan setiap 3 (tiga) bulan sekali dan belanja ini belum diklasifikasikan menjadi belanja dalam bentuk transfer melainkan belanja tunai.,

3. Pemerintah Desa tidak menggunakan dokumen Surat Permintaan Pembayaran (SPP) melainkan hanya menggunakan dokumen berupa daftar pembayaran penghasilan tetap atau tunjangan.

4. Setiap waktu penerimaan penghasilan untuk perangkat desa, Bendahara Desa membuat daftar pembayaran penghasilan tetap Kepala Desa dan perangkat desa untuk dilakukan pencairan dana dari rekening desa.

5. Dicantumkan tanda tangan persetujuan Kepala Desa dan Bendahara Desa beserta namanama penerima dan jumlah masing-masing dana yang akan diterima sesuai dengan ketentuan yang telah ditetapkan dalam SK Kepala Desa ke dalam daftar nama-nama penerima.

6. Bendahara mengajukan daftar tersebut untuk dilakukan pencairan dana tunai dari bank.

7. Perangkat-perangkat desa yang akan menerima penghasilan tetap melakukan penandatanganan daftar pembayaran penghasilan tetap perangkat desa dan juga melakukan penandatanganan diatas materai Rp. 6.000 pada kuitansi pengeluaran yang sudah diverifikasi dan ditandatangani oleh Sekretaris Desa kemudian langsung dilakukan penyerahan dana dari Bendahara Desa kepada perangkat desa yang akan menerima.

8. Bendahara Desa melakukan penandatanganan di kuitansi tersebut sebagai bukti bahwa Bendahara telah melakukan pelunasan pembayaran penghasilan tetap kepada perangkat desa yang akan menerima kemudian kuitansi tersebut diserahkan kepada Kepala Desa 
untuk dilakukan penandatanganan sebagai bukti bahwa transaksi tersebut diketahui oleh Kepala Desa.

9. Bendahara Desa tidak melakukan pencatatan pada buku kas pembantu pajak dikarenakan belanja pegawai tidak dikenakan potongan pajak. Bendahara hanya melakukan pencatatan pada Buku Kas Umum dan Buku Bank Desa.

Untuk pencairan dana tunjangan bagi Kepala Desa dan BPD sumber dananya juga diambil dari alokasi dana desa. Adapun proses pencairannya sebagai berikut:

1. Bendahara membuatkan daftar rincian berupa pembayaran tunjangan untuk tunjangan Kepala Desa dan membuat daftar rincian pembayaran tunjangan untuk BPD.

2. Di dalam daftar tersebut dicantumkan nama penerima dan jumlah dana yang akan diterima sesuai yang telah ditetapkan, dan juga tanda tangan dari Bendahara Desa dan Kepala Desa untuk daftar rincian tunjangan Kepala Desa dan ditambah tanda tangan Ketua BPD.

3. Bendahara mengajukan rincian tersebut ke bank untuk melakukan pencairan dana.

4. Bendahara membuatkan kuitansi pengeluaran yang akan diverifikasi oleh Sekretaris Desa.

5. Penerima dana melakukan penandatanganan diatas materai Rp. 6.000 pada kuitansi tersebut kemudian langsung diserahkan dana tunjangan tersebut kepada penerima dana.

6. Bendahara menandatangani kuitansi tersebut sebagai tanda bukti bahwa Bendahara telah melakukan pelunasan pembayaran dan kemudian kuitansi tersebut diserahkan kepada Kepala Desa untuk ditandatangani sebagai bukti telah diketahui dan disetujui.

7. Bendahara melakukan pencatatan untuk belanja pegawai di Buku Kas Umum dan Buku Bank Desa.

Prosedur pengajuan Surat Perintah Pembayaran (SPP) belanja barang dan jasa. Pada belanja barang dan jasa, sumber dana yang digunakan oleh Pemerintah Desa Ongkaw Tiga juga sama yaitu menggunakan dana yang berasal dari alokasi dana desa.

1. Prosedur pengadaan alat tulis kantor.

- Pelaksana kegiatan melakukan survei pada toko yang bisa menyediakan alat tulis kantor dan estimasi harganya.

- Pelaksana kegiatan membuatkan nota pesanan yang mencantumkan jenis dan jumlah barang yang akan dibeli, harga satuan dan jumlah harga dan juga dicantumkan tanda tangan dari Kepala Desa.

- Nota pesanan diajukan kepada toko atau penyedia alat tulis kantor tersebut.

- Pelaksana kegiatan melakukan pemeriksaan barang. Apabila barang dalam keadaan baik maka dibuatkan dokumen berita acara pemeriksaan barang yang di dalamnya dilampirkan nama pemeriksa barang, jabatan, alamat, jenis barang yang dipesan, penjelasan barang dalam keadaan baik, dan dilengkapi tanda tangan dari pemilik toko, pemeriksa barang, dan Kepala Desa.

- Dilakukan penyerahan barang pesanan dan dibuatkan berita acara penerimaan barang yang melampirkan nama penerima, jabatan, alamat, jenis barang yang dipesan, harga satuan, jumlah harga, dan dilengkapi tanda tangan dari penyedia barang, yang menerima, dan Kepala Desa.

- Pelaksana kegiatan membuatkan surat pengantar permintaan pembayaran, dan Surat Permintaan Pembayaran (SPP) sesuai dengan jumlah yang akan dibayarkan yang telah tercantum di dalam faktur sekaligus pelaksana kegiatan melakukan penandatanganan.

- Pelaksana kegiatan mengajukan SPP kepada Sekretaris Desa untuk diverifikasi dan ditandatangani kemudian SPP diserahkan kepada Kepala Desa untuk disetujui pembayarannya. SPP yang diajukan terdiri dari SPP, Pernyataan Tanggung Jawab Belanja, dan lampiran bukti transaksi. 
- Bendahara Desa kemudian mencairkan dana dari rekening desa dan diserahkan kepada Pelaksana Kegiatan dan Bendahara melakukan penandatanganan di SPP sebagai bukti telah dibayar lunas.

- Bendahara Desa melakukan pencatatan pada Buku Kas Umum dan Buku Bank Desa. Jika total pembayaran pembelanjaan kurang dari Rp.1.000.000 maka tidak dikenakan pemotongan pajak dan jika total pembayaran pembelanjaan melebihi Rp.1.000.000 maka dikenakan pemotongan pajak. Jika terdapat pemotongan pajak maka Bendahara Desa akan melakukan transfer pemotongan pajak ke Kas Negara sesuai dengan pemotongan pajak yang telah dihitung. Kemudian setelah itu Bendahara Desa melakukan pencatatan pada buku kas pembantu pajak.

2. Prosedur proses pencairan dana perjalanan dinas.

- Setelah melakukan perjalanan dinas, perangkat desa yang akan menerima dana perjalanan dinas tersebut harus menyerahkan dokumen-dokumen yang menjadi bukti bahwa perangkat desa tersebut telah melakukan perjalanan dinas agar bisa dilakukan pencairan.

- Dokumen-dokumen tersebut diantaranya yaitu Surat Perintah Tugas, Surat Perjalanan Dinas, dan laporan hasil pelaksanaan perjalanan dinas.

- Setelah itu Bendahara Desa membuatkan kuitansi pengeluaran untuk perjalanan dinas tersebut yang akan diverifikasi oleh Sekretaris Desa dan disetujui oleh Kepala Desa.

- Setelah diverifikasi dan disetujui oleh Kepala desa, Bendahara menyerahkan dana perjalanan dinas tersebut kepada penerima kemudian penerima dan Bendahara menandatangani kuitansi tersebut sebagai bukti bahwa dana telah diserahkan Bendahara kepada penerima.

- Setelah itu Bendahara Desa melakukan pencatatan pada Buku Kas Umum dan Buku Bank Desa.

Prosedur pengajuan Surat Perintah Pembayaran (SPP) belanja modal. Sumber dana yang digunakan dalam belanja modal di Desa Ongkaw Tiga tahun 2017 yaitu ada sebagian dana yang diambil dari Alokasi Dana Desa (ADD) ada juga yang diambil dari SILPA ADD. Adapun proses terjadinya belanja modal di Desa Ongkaw Tiga yakni sebagai berikut:

1. Tim pelaksana kegiatan melakukan perencanaan mengenai kegiatan, pelaksana kegiatan melakukan proses survei untuk menentukan objek yang kira-kira bisa menjadi penyedia barang.

2. Tim pelaksana kegiatan membuat surat permintaan penawaran pengadaan barang. Di dalam surat tersebut dilampirkan daftar barang-barang yang dibutuhkan dan kemudian diserahkan surat tersebut kepada penyedia barang dan dilengkapi tanda tangan dari ketua tim pelaksana kegiatan dan Kepala Desa.

3. Apabila penyedia barang tersebut bersedia melaksanakan pekerjaan pengadaan barangbarang tersebut, penyedia barang membuat surat penawaran harga, daftar rincian penawaran harga barang serta dilampirkan fotocopy Surat Izin Usaha Perdagangan (SIUP) dan fotocopy Nomor Pokok Wajib Pajak (NPWP) untuk ditujukan kepada pelaksana kegiatan.

4. Pelaksana kegiatan dan penyedia barang melakukan pertemuan untuk membahas klarifikasi dan negosiasi harga.

5. Pelaksana kegiatan membuatkan berita acara tentang klarifikasi dan negosiasi harga berdasarkan dengan kesepakatan yang dihasilkan pada saat pertemuan klarifikasi dan negosiasi harga yang dilengkapi dengan tanda tangan pelaksana kegiatan, penyedia barang, dan Hukum Tua.

6. Pelaksana kegiatan membuat surat perjanjian kerja sama antara pelaksana kegiatan dengan penyedia barang. 
7. Pelaksana kegiatan membuatkan nota pesanan yang mencantumkan jenis dan jumlah barang yang akan dibeli, harga satuan dan jumlah harga dan juga dicantumkan tanda tangan dari Kepala Desa. Setelah dibuatkan nota pesanan, nota pesanan diajukan kepada penyedia barang yang sudah disepakati kerja sama tadi tersebut.

8. Pelaksana kegiatan melakukan pemeriksaan barang. Apabila barang dalam keadaan baik maka dibuatkan dokumen berita acara pemeriksaan barang yang di dalamnya dilampirkan nama pemeriksa barang, jabatan, alamat, jenis barang yang dipesan, penjelasan barang dalam keadaan baik, dan dilengkapi tanda tangan dari pemilik toko, pemeriksa barang, dan Kepala Desa.

9. Dilakukan penyerahan barang pesanan dan dibuatkan berita acara penerimaan barang yang di dalamnya melampirkan nama penerima, jabatan, alamat, jenis barang yang dipesan, harga satuan, jumlah harga, dan dilengkapi tanda tangan dari penyedia barang, penerima, dan Kepala Desa.

10. Pelaksana kegiatan membuatkan surat pengatar permintaan pembayaran, dan Surat Permintaan Pembayaran (SPP) sesuai dengan jumlah yang akan dibayarkan yang telah tercantum di dalam faktur.

11. Pelaksana kegiatan mengajukan SPP kepada Sekretaris Desa untuk diverifikasi dan ditandatangani. SPP yang diajukan terdiri dari SPP, pernyataan tanggung jawab belanja dan lampiran bukti transaksi. Kemudian SPP diserahkan kepada Kepala Desa untuk disetujui pembayarannya. Setelah disetujui oleh Kepala Desa, Bendahara Desa kemudian mencairkan dana dari rekening desa dan diserahkan kepada pelaksana kegiatan.

12. Pelaksana kegiatan melakukan pembayaran ke penyedia barang sekaligus dibuatkan berita acara pembayaran.

13. Bendahara Desa melakukan pencatatan pada buku kas umum dan buku bank desa. Jika total pembayaran pembelanjaan kurang dari Rp.1.000.000 maka tidak dikenakan pemotongan pajak dan jika total pembayaran pembelanjaan melebihi Rp.1.000.000 maka dikenakan pemotongan pajak. Jika terdapat pemotongan pajak maka Bendahara Desa akan melakukan transfer pemotongan pajak ke kas negara sesuai dengan pemotongan pajak yang telah dihitung kemudian melakukan pencatatan pada buku kas pembantu pajak.

\subsection{Pembahasan}

Analisis kepatuhan pengajuan Rencana Anggaran Biaya (RAB). Proses pengajuan Rencana Anggaran Biaya yang terjadi di Desa Ongkaw Tiga jika dikaitkan dengan aturan yang telah ditetapkan yaitu Permendagri Nomor 113 tahun 2014 yang mensyaratkan bahwa di dalam proses pengajuan RAB pihak yang berperan dalam pembuatan RAB yaitu pelaksana kegiatan yang diperankan oleh Kepala Seksi. Hal ini jika dikaitkan dengan proses RAB yang terjadi di Desa Ongkaw Tiga, telah tergambar bahwa Pelaksana Kegiatan sebagai pihak yang diperankan dalam penyusunan RAB diambil dari Kepala Seksi. Sehingga di dalam tataran ini dapat dikatakan telah sesuai dan telah dipatuhi. Pada pembuatan RAB yang diatur dalam Permendagri Nomor 113 tahun 2014 ada beberapa komponen yang harus ada di dalamnya yaitu, pencantuman nama desa, kecamatan dan tahun anggaran, pencantuman bidang kegiatan, jenis kegiatan, waktu pelaksanaan, sumber dana, output. Kemudian dalam rincian pendanaan, komponen yang harus ada di dalamnya yaitu, nomor, kode rekening, uraian, volume, harga satuan, jumlah, tanda tangan pengesahan/persetujuan oleh Kepala Desa, tanda tangan verifikasi oleh Sekretaris Desa, tanda tangan Pelaksana Kegiatan dan tempat dan tanggal penandatanganan. Hal ini jika dikaitkan dengan proses pembuatan RAB yang terjadi di Desa Ongkaw Tiga dapat dikatakan tidak dipatuhi sebab dalam pembuatan dokumen $\mathrm{RAB}$, format yang digunakan didalamnya tidak dicantumkannya tahun anggaran, bidang kegiatan, waktu pelaksanaan, sumber dana, output, tanda tangan pengesahan/persetujuan oleh Kepala Desa, dan tanda tangan verifikasi Sekretaris Desa. 
Dengan demikian, seluruh rangkaian proses pengajuan RAB yang terjadi di Desa Ongkaw Tiga jika dikaitkan dengan peraturan yang berlaku, hanya satu hal yang dapat dikatakan patuh yaitu pihak yang diperankan untuk menjadi Pelaksana Kegiatan diambil dari Kepala Seksi. Sisanya yang dilakukan oleh Pemerintah Desa Ongkaw Tiga dalam penyusunan RAB dapat dikatakan tidak dipatuhi sebab format dokumen RAB yang digunakan tidak sesuai dengan aturan yang ada. Setelah dilakukan evaluasi, faktor yang menyebabkan terjadinya ketidakpatuhan dalam penyusunan $\mathrm{RAB}$ yaitu ketidaktahuan atau kurangnya pemahaman dari aparat desa bagaimana cara penyusunan RAB yang sesuai dengan peraturan yang berlaku.

Analisis kepatuhan pengajuan belanja pegawai. Dari seluruh rangkaian prosedur belanja pegawai yang telah dijalankan oleh Pemerintah Desa Ongkaw Tiga jika dikaitkan dengan peraturan yang ada yaitu Permendagri nomor 113 tahun 2014, dapat dilihat bahwa sebagian prosedur telah dilaksanakan sesuai aturan atau telah dipatuhi. Diantaranya, semua pengeluaran dilaksanakan melalui rekening desa, semua pengeluaran dilengkapi bukti yang lengkap dan sah, tidak adanya pungutan apapun dari pemerintah desa, setiap pencairan dana dilakukan oleh Bendahara Desa, semua dokumen diverifikasi oleh Sekretaris Desa, diketahui oleh Kepala Desa, pengeluaran dicatat dalam Buku Kas Umum dan Buku Bank Desa. Hanya saja masih terdapat beberapa prosedur yang masih belum dipatuhi. Terhadap hal yang belum dipatuhi yaitu belanja pegawai yang dilakukan hanya setiap 3 (tiga) bulan sekali dan tidak dikenakan pemotongan Pajak Penghasilan (PPh). Sementara dalam Permendagri Nomor 113 tahun 2014 dijelaskan bahwa belanja pegawai harus dilakukan setiap sebulan sekali dan Bendahara Desa harus melakukan pemotongan pajak penghasilan (PPh). Setelah dilakukan evaluasi, faktor yang mempengaruhi ketidakpatuhan pemerintah desa dalam menjalankan prosedur pengajuan belanja desa yaitu kurangnya pengetahuan dan pemahaman aparatur desa terhadap aturan yang diberlakukan, oleh sebab itu aparatur desa kedepannya diharapkan agar harus bisa mengetahui aturan-aturan yang berlaku dan bahkan kalau kalau bisa perlu juga dibuatkan pelatihan-pelatihan mengenai tugas-tugas perangkat desa. Dengan demikian diharapkan bisa meminimalisir terjadinya kesalahan-kesalahan.

Analisis kepatuhan pengajuan Surat Perintah Pembayaran (SPP) belanja barang dan jasa. Dari seluruh rangkaian prosedur pengajuan SPP belanja barang dan jasa yang dilakukan oleh Pemerintah Desa Ongkaw Tiga, dilihat bahwa hampir semua yang dipersyaratkan dalam Permendagri Nomor 113 tahun 2014 dapat dikatakan telah dipatuhi diantaranya, SPP diterbitkan sesudah barang atau jasa diterima, dokumen SPP terdiri dari SPP, Pernyataan Tanggung Jawab Belanja dan bukti transaksi, dokumen SPP di verifikasi oleh Sekretaris Desa dan disetujui oleh Kepala Desa, pencairan dana dilakukan oleh Bendahara melalui rekening desa, dicatat pada buku kas umum dan buku bank desa dan jika dikenakan potongan pajak bendahara menyetorkannya ke kas negara. Terhadap hal yang tidak dipatuhi yaitu tidak disusunnya penyusunan RAB dalam belanja barang dan jasa. Padahal di dalam belanja barang dan jasa khususnya pembelian ATK dan benda pos diperlukan pelaksana kegiatan untuk merealisasikan kegiatan tersebut. Permendagri Nomor 113 tahun 2014 dijelaskan bahwa pelaksana kegiatan dalam melakukan pendanaan untuk melaksanakan kegiatan harus disertai dengan dokumen antara lain RAB.

Analisis kepatuhan pengajuan Surat Perintah Pembayaran (SPP) belanja modal. Setelah dilihat dari seluruh rangkaian prosedur belanja modal hingga pengajuan SPP yang telah dijalankan di Desa Ongkaw Tiga, pada umumnya telah dilaksanakan sesuai dengan aturan. Hanya saja dikarenakan format dokumen RAB yang digunakan untuk melakukan pengajuan pendanaan atau SPP tidak sesuai dengan aturan yang berlaku maka secara administratif dapat dikatakan proses pengajuan SPP belanja modal yang terjadi di Desa Ongkaw Tiga tidak dipatuhi. Tabel 1 menyajikan keseluruhan hasil penelitian atas uji kepatuhan prosedur pengajuan RAB, belanja pegawai, SPP belanja barang dan jasa, dan SPP belanja modal. 
Tabel 1. Uji kepatuhan prosedur pengajuan RAB, belanja pegawai, SPP belanja barang dan jasa, dan SPP belanja modal

\begin{tabular}{l}
\hline Permendagri No. 113 tahun 2014 \\
\hline Pada pembuatan RAB ada beberapa \\
komponen yang harus ada di dalamnya \\
yaitu, pencantuman nama desa, \\
kecamatan dan tahun anggaran, \\
pencantuman bidang kegiatan, jenis \\
kegiatan, waktu pelaksanaan, sumber \\
dana, output. Kemudian dalam rincian \\
pendanaan, komponen yang harus ada di \\
dalamnya yaitu, nomor, kode rekening, \\
uraian, volume, harga satuan, jumlah, \\
tanda tangan pengesahan/persetujuan \\
olehKepala Desa, tanda tangan verifikasi \\
oleh Sekretaris Desa, tanda tangan \\
Pelaksana Kegiatan dan tempat dan \\
tanggal penandatanganan.
\end{tabular}

Pada belanja pegawai, semua pengeluaran harus dilaksanakan melalui rekening desa, semua pengeluaran dilengkapi bukti yang lengkap dan sah, tidak adanya pungutan apapun dari pemerintah desa, setiap pencairan dana dilakukan oleh Bendahara Desa, semua dokumen diverifikasi oleh Sekretaris Desa, diketahui oleh Kepala Desa, pengeluaran dicatat dalam Buku Kas Umum dan Buku Bank Desa.

Pada belanja pegawai, dipersyaratkan bahwa belanja pegawai dilakukan setiap sebulan sekali dan Bendahara Desa harus melakukan pemotongan pajak penghasilan $(\mathrm{PPh})$.

SPP diterbitkan sesudah barang atau jasa diterima, dokumen SPP terdiri dari SPP, Pernyataan Tanggung Jawab Belanjadan Bukti transaksi, dokumen SPP di verifikasi oleh Sekretaris Desa dan disetujui oleh Kepala Desa, pencairan dana dilakukan oleh Bendahara melalui rekening desa, dicatat pada buku kas umum dan buku bank desa dan jika dikenakan potongan pajak bendahara menyetorkannya ke kas negara.

Dalam melaksanakan belanja barang dan jasa, pelaksana kegiatan dalam melakukan pendanaan untuk melaksanakan kegiatan harus disertai dengan dokumen antara lain Rencana Anggaran Biaya (RAB).

Dalam pelaksanaan belanja di desa, pelaksana kegiatan mengajukan pendanaan untuk melaksanakan kegiatan harus disertai RAB, RAB diverifikasi oleh sekretaris desa dan disahkan oleh kepala desa, berdasarkan RAB pelaksana kegiatan mengajukan SPP, SPP tidak boleh dilakukan barang atau jasa diterima, SPP terdiri atas SPP,

Pengeluaran dilaksanakan melalui rekening desa, pengeluaran dilengkapi bukti yang lengkap dan sah, tidak adanya pungutan apapun dari pemerintah desa, setiap pencairan dana dilakukan oleh Bendahara Desa, semua dokumen diverifikasi oleh Sekretaris Desa, diketahui oleh Kepala Desa, pengeluaran dicatat dalam Buku Kas Umum dan Buku Bank Desa.

Belanja pegawai yang dilakukan hanya setiap tiga bulan sekali dan tidak dikenakan pemotongan pajak penghasilan (PPh).

SPP diterbitkan sesudah barang atau jasa diterima, dokumen SPP terdiri dari SPP, Pernyataan Tanggung Jawab Belanjadan Bukti transaksi, dokumen SPP di verifikasi oleh Sekretaris Desa dan disetujui oleh Kepala Desa, pencairan dana dilakukan oleh Bendahara melalui rekening desa, dicatat pada buku kas umum dan buku bank desa dan jika dikenakan potongan pajak bendahara menyetorkannya ke kas negara.

Tidak buat penyusunan RAB dalam belanja barang dan jasa.

Pelaksana kegiatan mengajukan pendanaan untuk melaksanakan kegiatan harus disertai RAB, RAB diverifikasi oleh sekretaris desa dan disahkan oleh kepala desa, berdasarkan RAB pelaksana kegiatan mengajukan SPP, SPP tidak boleh dilakukan barang atau jasa diterima, SPP terdiri atas SPP, pernyataan tanggung jawab belanja dan
Tidak patuh

Patuh

Tidak patuh

Tidak patuh 
Tabel 1. Uji kepatuhan prosedur pengajuan RAB, belanja pegawai, SPP belanja barang dan jasa, dan SPP belanja modal

Permendagri No. 113 tahun 2014

pernyataan tanggung jawab belanja dan lampiran bukti transaksi, SPP diverifikasi oleh sekretaris dan disahkan oleh kepala desa, jika terdapat pemotongan pajak bendahara desa sebagai waji pajak wajib menyetorkan ke rekening kas Negara.

Pelaksanaan Desa Ongkaw Tiga
lampiran bukti transaksi, SPP
diverifikasi oleh sekretaris dan disahkan
oleh kepala desa, jika terdapat
pemotongan pajak bendahara desa
sebagai waji pajak wajib menyetorkan ke
rekening kas Negara. Secara umum
sudah sesuai dengan Permendagri
Nomor 113 Tahun 2014. Namun karena
format RAB yang dibuat tidak sesuai
dengan aturan maka tetap dikatakan
tidak patuh.

Sumber: Data olah, 2020

Analisis pengendalian internal Committee of Sponsoring Organizations of the Treadway Commission (COSO). Menganalisis sistem pengendalian terhadap penatausahaan belanja di Desa Ongkaw Tiga, maka penelitian ini menggunakan konsep pengendalian internal menurut Committee of Sponsoring Organizations of the Treadway Commission (COSO). Teori ini menyatakan bahwa pengendalian internal itu memadai apabila memenuhi beberapa aspek yaitu lingkungan pengendalian, penaksiran risiko, kegiatan pengendalian, informasi dan komunikasi, dan pemantauan (monitoring).

1. Lingkungan pengendalian. Aparat desa yang ditugaskan untuk menjadi Pelaksana Kegiatan sudah dipilih mengikuti prosedur yaitu diambil dari Kepala Seksi. Namun dalam pelaksanaannya tidak ada alat ukur untuk menentukan terkait penentuan kompetensi dengan persyaratan tertentu untuk melaksanakan tanggung jawab tersebut. Kepala Seksi hanya ditugaskan berdasarkan keinginan dari Kepala Desa. Sehingga tugas yang dilaksanakan oleh Kepala Seksi sebagai Pelaksana Kegiatan hanya berdasarkan kebiasaan yang berlaku selama ini. Seharusnya di dalam menjalankan tugas sebagai pelaksana kegiatan, harus ada dokumen yang tertulis untuk djadikan acuan tugas apa yang harus dikerjakannya. Dengan demikian aspek pengendalian atas berjalannya suatu mekanisme pekerjaan tidak akan maksimal dan mengandung risiko tidak terlaksananya prosedur sesuai aturan, bahkan berpotensi terjadinya penyimpangan.

2. Penaksiran risiko. Dari segi penaksiran risiko pada pemerintah Desa Ongkaw Tiga dapat dikatakan belum berjalan dengan baik, dimana pada proses penyusunan RAB, belanja pegawai, dan pengajuan SPP didapati ada beberapa komponen-komponen yang menjadi syarat di dalam dalam prosedur tersebut tidak dipenuhi atau tidak sesuai dengan aturan yang diberlakukan. Hal ini dapat mengakibatkan terjadinya risiko penyimpanganpenyimpangan dalam prosedur-prosedur tersebut. Belanja pegawai seharusnya dilakukan sebulan sekali namun Pemerintah Desa Ongkaw Tiga melakukannya setiap 3 (tiga) bulan sekali dan tidak dikenakan pemotongan Pajak Penghasilan (PPh) sehingga berdampak pada potensi berkurangnya pendapatan negara yang bersumber dari pungutan pajak.

3. Kegiatan pengendalian. Kegiatan pengendalian yang terjadi di Desa Ongkaw Tiga dapat dikatakan belum terpenuhi. Hal ini disebabkan karena di dalam penyusunan dokumendokumen belanja Pelaksana Kegiatan tidak mengikuti prosedur yang semestinya. Tidak semua dokumen yang diproses diverifikasi oleh Sekretaris Desa dan juga ada beberapa dokumen yang tidak ada persetujuan oleh Kepala Desa. Ketika telah terjadi ketidakpatuhan aturan dalam proses-proses tersebut, pemerintah desa yang berwenang tidak melakukan tindakan atau memberikan solusi yang berfungsi untuk memperbaiki kesalahan-kesalahan yang telah terjadi.

4. Informasi dan komunikasi. Informasi dan komunikasi di Desa Ongkaw Tiga sebagian tidak berjalan dengan baik, dimana dalam penyusunan sebagian dokumen tidak adanya komunikasi yang baik antara Pelaksana Kegiatan, Sekretaris Desa, dan Kepala Desa 
sehingga seperti dalam penyusunan RAB tidak adanya proses verifikasi yang seharusnya dilaksanakan oleh Sekretaris Desa dan tidak adanya persetujuan oleh Kepala Desa.

5. Pemantauan (monitoring). Pemantauan dalam pengajuan belanja barang dan jasa di Desa Ongkaw Tiga yang dilakukan tidak berjalan dengan baik. Hal ini terlihat pada proses pengajuan SPP tidak disertakan dokumen RAB yang menjadi syarat dalam pengajuan SPP. Hal ini menggambarkan bahwa tidak adanya pemantauan atau monitoring secara rutin dari Kepala Desa.

\section{KESIMPULAN DAN SARAN}

\subsection{Kesimpulan}

Berdasarkan hasil penelitian dan pembahasan, maka dapat ditarik kesimpulan bahwa proses penatausahaan serta pengendalian internal yang diselenggarakan oleh Pemerintah Desa Ongkaw Tiga dalam pelaksanaan belanja desa belum memadai. Hal ini dapat dilihat dari beberapa faktor sebagai berikut:

1. Pemerintah Desa Ongkaw Tiga belum patuh dalam melakukan penyusunan RAB. Faktor yang menyebabkan terjadinya ketidakpatuhan dalam penyusunan RAB yaitu ketidaktahuan atau kurangnya pemahaman dari aparat desa bagaimana cara menyusun RAB yang sesuai dengan peraturan yang berlaku.

2. Proses belanja pegawai masih belum mematuhi beberapa ketentuan diantaranya pembayaran yang dilakukan setiap tiga bulan sekali dan tidak dikenakan Pajak Penghasilan (PPh). Permendagri Nomor 113 tahun 2014 menjelaskan bahwa belanja pegawai harus dilakukan setiap sebulan sekali dan Bendahara Desa harus melakukan pemotongan Pajak Penghasilan ( $\mathrm{PPh}$ ). Hal ini menggambarkan bahwa pengendalian internal yang dilakukan oleh Pemerintah Desa Ongkaw Tiga belum maksimal.

3. Pada prosedur pengajuan SPP belanja barang dan jasa dapat dilihat bahwa hampir semua yang dipersyaratkan dalam Permendagri Nomor 113 tahun 2014 telah dipatuhi. Hanya ada satu hal yang tidak dilaksanakan oleh Pemerintah Desa Ongkaw Tiga yaitu tidak menyusun RAB dalam belanja barang dan jasa padahal belanja barang dan jasa khususnya pembelian ATK dan benda pos diperlukan pelaksana kegiatan untuk merealisasikan kegiatan tersebut. Permendagri Nomor 113 tahun 2014 menyatakan bahwa pelaksana kegiatan dalam melakukan pendanaan untuk melaksanakan kegiatan harus disertai dengan dokumen antara lain Rencana Anggaran Biaya (RAB).

4. Pada proses pengajuan SPP belanja modal yang telah dilaksanakan oleh Desa Ongkaw Tiga pada prinsipnya telah dilaksanakan dengan baik hanya saja pada dasarnya dokumen RAB yang digunakan dalam pengajuan pendanaan atau SPP tidak sesuai aturan yang berlaku,maka tetap dikatakan tidak patuh.

\subsection{Saran}

Berdasarkan kesimpulan diatas, maka penelitian ini menyarankan agar aparatur desa yang ditugaskan harus mengetahui aturan-aturan yang berlaku dan juga diharapkan kepada Kepala Desa agar bisa menjalin kerja sama dengan Tim Pendamping tingkat kecamatan untuk mencarikan solusi atas masalah tersebut. Misalnya, memfasilitasi dan mengadakan sosialisasi atau pelatihan untuk perangkat desa. Dengan demikian diharapkan dengan sebab kegiatan tersebut bisa meminimalisir terjadinya kesalahan-kesalahan. 


\section{DAFTAR PUSTAKA}

COSO. (2013). Internal control-Integrated framework: Executive summary. Durham, North California.

Gimon, H. P., Tinangon, J. J., \& Affandi, D. (2018). Analisis sistem akuntansi pelaksanaan APBDes pada pemerintah desa Kopandakan I Kecamatan Kotamobagu Selatan Kota Kotamobagu. Jurnal Riset Akuntansi Going Concern, 13(2), 1-10. https://doi.org/10.32400/gc.13.02.19068.2018

Halim, A. (2012). Akuntansi keuangan daerah. Jakarta: Salemba Empat.

Lapananda, Y. (2016). Hukum pengelolaan keuangan desa, Buku 1. Jakarta: Penerbit Rmbooks.

Mamesah, F. Y. (2015). Peranan Badan Permusyawaratan Desa dalam penyusunan anggaran pendapatan dan belanja desa (Suatu studi di Desa Sendangan Kecamatan Tompaso). Jurnal Politico, 4(1), 1-11. https://ejournal.unsrat.ac.id/index.php/politico/article/view/8510

Mulyadi. (2016). Sistem akuntansi. Jakarta: Salemba Empat.

Nafidah, L. N., \& Anisa, N. (2017). Akuntabilitas pengelolaan keuangan desa di Kabupaten Jombang. Akuntabilitas: Jurnal Ilmu Akuntansi, 10(2), 273-288. http://journal.uinjkt.ac.id/index.php/akuntabilitas/article/view/5936

Noverman, Y. (2018). Analisis kesesuaian pengelolaan dana desa dengan peraturan perundang-undangan (Studi kasus di Nagari Bukit Bual Kabupaten Sijunjung). Jurnal Analisis Kebijakan dan Pelayanan Publik, 4(2), 68-61. http://journal.unhas.ac.id/index.php/jakpp/article/view/5383

Peraturan Menteri Dalam Negeri Nomor 113 tahun 2014 tentang Pengelolaan Keuangan Desa. Republik Indonesia. Jakarta.

Sadeli, L. (2015). Dasar-dasar akuntansi, Edisi pertama. Jakarta: Bumi Aksara.

Setiawan, M. W., Atmadja, A. T., \& Sulindawati, N. L. G. E. (2017). Analisis transparansi dan akuntabilitas pelaporan alokasi dana desa (Studi kasus Desa Bengkel Kec. Busungbiu, Kab. Buleleng). Jurnal Ilmiah Mahasiswa Akuntansi Undiksha, 7(1), 111. https://ejournal.undiksha.ac.id/index.php/S1ak/article/view/10151

Tangkaroro, K., Ilat, V., \& Wokas, H. (2017). Penerapan sistem dan prosedur akuntansi pengelolaan dana desa di Desa Tincep Kecamatan Sonder Kabupaten Minahasa. Going Concern: Jurnal Riset Akuntansi, 12(2), 671-680. https://doi.org/10.32400/gc.12.2.18007.2017

Undang-Undang Republik Indonesia Nomor 6 tahun 2014 tentang Desa.

Usman, F., \& Haryanto, S. D. (2015). Analisis kesiapan pemerintah desa dalam pengelolaan dana desa (Studi kasus pada pemerintah Desa Pelawad Kecamatan Ciruas Kabupaten Serang). JIA: Jurnal Info Artha, 31-37. http://jurnal.pknstan.ac.id/index.php/JIA/article/view/104

Wiratna, S. (2015). Akuntansi sektor publik. Yogyakarta: Pustaka baru press. 